https://nv.nltu.edu.ua

https://doi.org/10.15421/40280606

Article received 15.06.2018 $\mathrm{p}$.

Article accepted 25.06.2018 p.

\title{
АРХІТЕКТУРНО-ПЛАНУВАЛЬНІ ОСОБЛИВОСТІ ФОРМУВАННЯ ВУЛИЧНИХ НАСАДЖЕНЬ МІСТА ЛЬВОВА
}

\begin{abstract}
Проаналізовано принципи, прийоми та планувальні особливості озеленення вздовж основних вулиць Франківського району Львова. Здійснено огляд сучасних досліджень у сфері вуличного озеленення. Наведено технічну характеристику десяти вулиць міста за їх параметрами, планувальною структурою та орієнтацією за сторонами світу. Вивчено породний склад рядових посадок, який загалом налічує 20 видів дерев. Проаналізовано їх розміщення, умови зростання, кількісні та якісні показники озеленення досліджених об'єктів. Виявлено присутність у цьому районі всіх найтиповіших прийомів вуличного озеленення. Найчастіше трапляються посадки одного ряду дерев між проїзною частиною і тротуаром чи лише смуги газону. Значне переважання дерев у лунках виявлено за умов щільної забудови району. Встановлено залежність рівня озеленення обраних вулиць від характеру і часу забудови: у старій частині довжина ділянок дороги зі зеленими насадженнями змінюється в межах 46,1-60,6 \%, тоді як нові мікрорайони з магістральними дорогами добре озеленені майже по всій довжині. Виявлено порушення щодо розмірів садивних площ, а також розташування насаджень вздовж вулиць. Оцінено функціональну здатність придорожніх зелених смуг. Зафіксовано проблеми під час проектування нових посадок. Узагальнено основні недоліки озеленення вздовж відібраних для дослідження вулиць.
\end{abstract}

Ключові слова: вулиці; рядові посадки; озеленення; принципи проектування.

Вступ. Зеленим насадженням завжди відводилася важлива роль на вулицях міст, зокрема для створення художньо-естетичного середовища проживання їх мешканців. В останні роки насадження вздовж вулиць, доріг, проїздів дедалі частіше використовують для поліпшення умов перебування людини в міському середовищі. Вони повинні забезпечувати захист населення від шуму, пилу, вихлопних газів, покращувати мікроклімат, відповідати архітектурно-художнім вимогам і умовам безпеки руху (видимість руху транспортних засобів, пішоходів, засобів регулювання руху).

Теоретичні засади формування вуличних насаджень розробили багато відомих ландшафтних архітекторів: В. Ф. Гостев, Н. Н. Юскевич, І. О. Боговая, А. П. Вергунов та ін. Вони запропонували основні планувальнокомпозиційні та інженерно-технічні принципи i прийоми закладання зелених насаджень вздовж вулиць 3 урахуванням їх біолого-екологічних особливостей.

Сучасні дослідження у цій сфері можна звести до кількох напрямів. По-перше, вивчають видове різноманіття вуличних насаджень на основі подеревної інвентаризації (Atkina \& Vishniakova, 2015; Melnyk \& Melnyk, 2013; Hanaba, 2016; Suslova, 2017; Litvinenko, Vikluyk \& Blyakharska, 2017; McPherson, van Doorn \& de Goede, 2016). У великій кількості наукових робіт проаналізовано чинники негативного впливу на міські зелені насадження та показники життєздатності рослинних організмів за таких умов (Kravchuk \& Ryzhikov, 2011; Pihalo, 2014; Kurnycka, 2001; Koeser et al., 2013). Збільшується кількість досліджень санітарно-гігієнічних функцій вуличних зелених насаджень, особливо їх пило-, газо- i шумопоглинальна роль (Balakin, 2015; Vailshery, Jaganmohan \& Nagendra, 2013; Seamans, 2013). У підсумку, результати всіх наведених вище досліджень зводяться здебільшого до узагальнення критеріїв та рекомендацій щодо підбору оптимального асортименту урбогенно стійких видів дерев і кущів (Szafranko, 2012; Borowski \& Latocha, 2006). Водночас замало уваги приділяють вибору правильних засобів озеленення, аналізу принципів формування вуличних насаджень у сучасному місті, основних недоліків у композиції та розташуванні, що $\epsilon$ важливим і потрібним завданням сьогодення для розробки системи оптимізації міського середовища.

Метою дослідження є аналіз планувальних особливостей та композиційних прийомів формування вуличного озеленення великого міста на прикладі насаджень Львова.

Об'єкти $і$ методика дослідження. Дослідження здійснювали на основних вулицях у межах Франківського p-ну за допомогою натурних обстежень, подеревної інвентаризації (Instrukcija, 2001) та карт Google.

Франкі́вський райо́н - один із районів Львівської міськради, що охоплює територію центрально-південної частини Львова. Створено 15 квітня 1973 р. як Радянський район Львова. У 90-ті роки ХХ ст. отримав свою теперішню назву.

Умовно Франківський р-н можна поділити на дві частини. Перша, стара частина, тягнеться від вул. Бан-

\section{Інформація про авторів:}

Курницька Марта Петрівна, канд. с.-г. наук, доцент. Email: kurnytskam@gmail.com

Цитування за ДСту: Курницька М. П. Архітектурно-планувальні особливості формування вуличних насаджень міста Львова. Науковий вісник НЛтУ України. 2018, т. 28, № 6. С. 35-38.

Citation APA: Kurnytska, M. P. (2018). Some architectural and planning features of street landscaping of the city of Lviv. Scientific Bulletin of UNFU, 28(6), 35-38. https://doi.org/10.15421/40280606 
дери до залізничної колії. Тут переважає забудова кінця XIX ст. та довоєнна престижна малоповерхова котеджна забудова. Основними вулицями в цій частині $є$ Героїв УПА, Антоновича, Ген. Чупринки, Сахарова, Коновальця. Друга частина Франківського р-ну обмежена чотирикутником вулиць Володимира Великого - Кульпарківської - Наукової - Стрийської, який перетинається вул. Княгині Ольги. Забудова здебільшого багатоповерхова - "хрущовки", а також будинки у стилі конструктивізму 70-90-х років XX ст. В обох частинах району $\epsilon$ вкраплення сучасної забудови 2000-2017-х років.

Результати дослідження та їх обговорення. На характер озеленення впливає багато планувальних чинників самої вулиці, тому їх аналіз важливий під час дослідження (табл. 1). Найдовшою серед вибраних $\epsilon$ вул. Кульпарківська - завдовжки 3800 м, а найкоротшою вул. Тролейбусна - 1300 м. Ширина вулиць змінюється в межах 6-12 м, а 3 роздільними смугами - 2630 м. При цьому ширина самих смуг становить 6 м. Такі вулиці характеризуються інтенсивним і багаторядним рухом транспорту (вул. В. Великого, Кульпарківська, Кн. Ольги та Наукова).

Табл. 1. Аналіз основних параметрів вулиць

\begin{tabular}{|c|l|c|c|c|}
\hline $\begin{array}{c}\text { № } \\
\text { 3/п }\end{array}$ & \multicolumn{1}{|c|}{ Назва вулиці } & $\begin{array}{c}\text { Довжина } \\
\text { вулиці, м }\end{array}$ & $\begin{array}{c}\text { Ширинайждж. } \\
\text { прост., м }\end{array}$ & $\begin{array}{c}\text { Орієнтація } \\
\text { вулиці }\end{array}$ \\
\hline 1 & Вул. Сахарова & 1900 & 8,0 & $\begin{array}{c}\text { Пн.Сх.-Пд.3х. } \\
\text { Пн.3х.-Пд.сх. }\end{array}$ \\
\hline 2 & Вул. Кн. Ольги & $3200^{*}$ & 26,0 & Пн.Сх.-Пд.3х. \\
\hline 3 & Вул. Ген. Чупринки & 2000 & 5,0 & Пн.Сх.-Пд.3х. \\
\hline 4 & Вул. Коновальця & 1650 & 5,0 & Пн.Сх-Пд.3х \\
\hline 5 & Вул. Антоновича & 1600 & 5,5 & Пн.Сх-Пд.3х \\
\hline 6 & Вул. Героїв УПА & 1400 & 6,0 & Пн.Сх-Пд.3х \\
\hline 7 & Вул. Кульпарківська & 3800 & $9,0-12,0$ & Пн.-Пд. \\
\hline 8 & Вул. В. Великого & 2500 & 12,0 & Сх.-Зх. \\
\hline 9 & Вул. Наукова & $2700^{*}$ & 30,0 & Сх.-Зх. \\
\hline 10 & Вул. Тролейбусна & 1300 & 5,0 & Пн.-Пд. \\
\hline
\end{tabular}

Примітка: * з роздільною смугою

Насадження вздовж основних вулиць Франківського p-ну м. Львова представлені досить широким асортиментом рослин. Їх кількісний склад змінюється в межах вулиці від 2 до 12 видів. Усього асортимент деревних порід на наших вулицях становить 20 видів. Серед них лідируючі позиції займають Tilia platyphyllos Scop., Aesculus hippocastanum L., Acer platanoides L. та Fraxinus excelsior L. (рисунок). Найбагатший асортимент видів на вул. Героїв УПА, Ген. Чупринки та Сахарова (12, 10 та 9 відповідно). Водночас деякі вулиці мають дуже однорідний видовий склад. Так, на вул. Тролейбусній та В. Великого зустрічаємо лише Tilia platyphyllos Scop. та Tilia cordata Mill., а на вул. Коновальця переважно зростає Aesculus hippocastanum L.

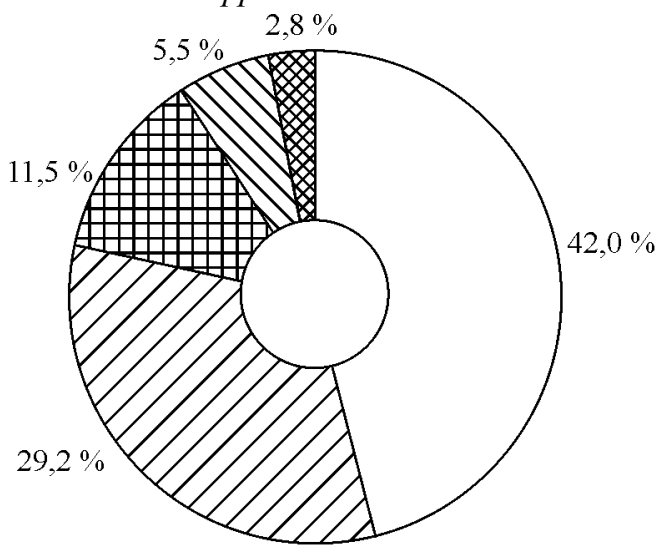

$\square$ Tilia platyphyllos Scop.
Aesculus hippocastanum L.
Acer saccharinum $L$.
Acer platanoides $L$.

Рисунок. Спектр переважаючих видів дерев

Середній вік обстежених дерев становить близько 40 років. Найстаріші екземпляри зростають на вул. Коновальця (80-100 років), а наймолодші насадження виявлено на вул. Кн. Ольги (10-15 років).

У цьому районі міста присутні всі найтиповіші прийоми вуличного озеленення. Часто трапляються озеленення у вигляді насаджень одного ряду дерев між проїзною частиною і тротуаром чи лише смуги газону (загальна довжина 11800 м та 3650 м відповідно, табл. 2). У районах старої забудови дерева зростають здебільшого в лунках. Довжина таких насаджень сумарно становить близько $3500 \mathrm{M}$.

Табл. 2. Аналіз прийомів озеленення вулиць у Франківському р-ні

\begin{tabular}{|c|c|c|c|c|c|c|c|c|}
\hline \multirow[b]{2}{*}{$\begin{array}{l}\text { № } \\
3 / \Pi\end{array}$} & \multirow[b]{2}{*}{ Назва вулиці } & \multicolumn{2}{|c|}{ Довжина зеленої смуги, м } & \multirow{2}{*}{$\begin{array}{l}\text { Ширина } \\
\text { смуги } 3 \text { де- } \\
\text { ревами, м }\end{array}$} & \multirow[b]{2}{*}{$\begin{array}{c}\text { Рядність } \\
\text { насаджень }\end{array}$} & \multirow{2}{*}{$\begin{array}{c}\text { Ширина прибудин- } \\
\text { кового озеленення, } \\
\text { м }\end{array}$} & \multirow{2}{*}{$\begin{array}{c}\text { Довжина ву- } \\
\text { лиці з лунка- } \\
\text { ми дерев, м }\end{array}$} & \multirow[b]{2}{*}{$\begin{array}{c}\text { \% озеле- } \\
\text { нення* }\end{array}$} \\
\hline & & $\begin{array}{l}\text { лише } \\
\text { газон }\end{array}$ & $\begin{array}{c}3 \text { деревними наса- } \\
\text { дженнями }\end{array}$ & & & & & \\
\hline 1 & вул. Сахарова & 20 & 950 & $1,0-1,5$ & $1 \mathrm{p}$. & $10-20$ & 630 & 84,2 \\
\hline 2 & вул. Кн. Ольги & 2600 & 1020 & $1,5-5,0$ & $1 \mathrm{p}$. & $10-25$ & - & 67,0 \\
\hline 3 & вул. Ген. Чупринки & - & 500 & 1,2 & $1 \mathrm{p}$. & $5-15$ & 610 & 55,5 \\
\hline 4 & вул. Коновальця & - & - & - & $1 \mathrm{p}$. & 10 & 1400 & 90,3 \\
\hline 5 & вул. Антоновича & - & 130 & 1,2 & $1 \mathrm{p}$. & - & 870 & 60,6 \\
\hline 6 & вул. Героїв УПА & 45 & 130 & 2,0 & $1 \mathrm{p}$. & - & 480 & 46,1 \\
\hline 7 & вул. Кульпарківська & 328 & 3320 & $5-15$ & $1 \mathrm{p}$. & $15-20$ & - & 89,3 \\
\hline 8 & вул. В. Великого & 180 & 2200 & 7 & $1 \mathrm{p}$. & $5-22$ & 20 & 95,2 \\
\hline 9 & вул. Наукова & 475 & 2010 & $1,5-21$ & $1-2 \mathrm{p}$. & $8-60$ & - & 92,0 \\
\hline 10 & вул. Тролейбусна & - & 1200 & $4-8$ & $1 \mathrm{p}$. & $8-14$ & - & 92,3 \\
\hline
\end{tabular}

Примітка: *відношення озеленених ділянок до загальної довжини вулиці.

Важливим є аналіз ширини зелених придорожніх смуг. Мінімальний їх розмір під час насадження одного ряду дерев між проїжджою частиною і тротуаром приймається 3 м, під час двох рядів - 5 м (ДБН В.2.3-52001). Згідно з нашими дослідженнями, такі вимоги виконуються лише на вулицях новіших житлових районів. В умовах старої забудови внаслідок нестачі вільних площ ширина цих смуг становить 1-2 м (вул. Сахарова, Ген. Чупринки, Антоновича, Героїв УПА).
Найкращий рівень вуличного озеленення відзначено на вул. Науковій, де на широких зелених смугах подекуди розташовуються 2 ряди дерев, а на значній довжині дороги, окрім них, присутнє і прибудинкове озеленення, ширина якого місцями становить 60 м. Прибудинкові зелені території значно рідше спостерігаємо на вул. Антоновича, Ген. Чупринки, Героїв УПА і переважно вони представлені присадибними ділянками зелені. 
Кількість насаджень та характер їх розміщення на досліджуваних об'єктах теж різняться. На вулицях зі щільною забудовою (вул. Антоновича, Ген. Чупринки, Героїв УПА) довжина ділянок зелені незначна і становить відповідно 60,6 \%, 55,5 \% і 46,1 \%. Водночас нові мікрорайони 3 магістральними дорогами добре озеленені майже по всій довжині. Так, вул. В. Великого та Наукова обсаджені з обох боків більше як на $90 \%$ всієї протяжності.

Аналіз відповідності існуючого характеру озеленення вулиць до нормативних показників здійснено на основі табл. 2. На жаль, на цих об'єктах переважають значно менші від допустимих розміри лунок (за норми $2,0 \times 2,0$ м), в яких подекуди зростають дерева I величи- ни (табл. 3). Зауважимо, що зменшення розмірів часто відбувається після реконструкції тротуарів. Такі обмеження відкритих грунтових площ дуже ускладнюють умови зростання дерев. А надгрунтові захисні решітки виявлено лише на вул. Сахарова в місцях організованого паркування машин.

На міських вулицях дерева часто страждають від механічних пошкоджень, спричинених рухомим транспортом. Згідно з нормами насадження, допустима відстань від осі дерев до проїжджої частини має становити не менше 2,0 м. Здебільшого на наших об'єктах щільної забудови ця відстань становить 1,0-1,5 м. Лише завдяки обрізуванню нижніх гілок деревам вдається уникати значних травм і пошкоджень.

Табл. 3. Планувальний аналіз вуличного озеленення

\begin{tabular}{|c|c|c|c|c|c|c|}
\hline $\begin{array}{c}\text { № } \\
\text { 3/п }\end{array}$ & Назва вулиці & Розмір лунок, м & $\begin{array}{c}\text { Відстань від проїж- } \\
\text { джої частини, }\end{array}$ & $\begin{array}{c}\text { Відстань від тро- } \\
\text { туару, м }\end{array}$ & $\begin{array}{c}\text { Відстань від за- } \\
\text { будови, м }\end{array}$ & $\begin{array}{c}\text { Лунки без де- } \\
\text { рев, шт. }\end{array}$ \\
\hline 1 & вул. Сахарова & $1,2 \times 1,2$ & $1,3-3,0$ & $0,5-1,0$ & $5-25$ & 1 \\
\hline 2 & вул. Кн. Ольги & - & $3,0-7,0$ & $1,0-2,0$ & $2-15$ & - \\
\hline 3 & вул. Ген. Чупринки & $1,0 \times 1,0,1,5 \times 1,5$ & $2,0-4,0$ & $0,5-1,0$ & $3-5$ & - \\
\hline 4 & вул. Коновальця & $1,2 \times 1,5,1,7 \times 1,7$ & $0,5-1,5$ & на тротуарі & 7 & 5 \\
\hline 5 & вул. Антоновича & $1,0-1,0$ & 1,0 & 0,5 & 2,5 & - \\
\hline 6 & вул. Героїв УПА & $1,0-1,5$ & 1,0 & 1,0 & $2,0-6,0$ & 12 \\
\hline 7 & вул. Кульпарківська & - & 2,5 & $0,5-1,0$ & $5-10$ & - \\
\hline 8 & вул. В. Великого & - & $2,0-5,0$ & $1,0-4,0$ & $10-30$ & - \\
\hline 9 & вул. Наукова & - & $2,5-3,0$ & $1,0-2,0$ & $5-60$ & - \\
\hline 10 & вул. Тролейбусна & - & $2,0-6,0$ & $1,0-2,0$ & $2-20$ & - \\
\hline
\end{tabular}

Порушення допустимої (5 м) відстані розташування насаджень відносно стін будинків спостерігаємо теж в умовах малоповерхової старої забудови (вул. Героїв УПА, Антоновича та Ген. Чупринки). Позитивно відрізняється проектування насаджень на вул. Коновальця, де витримані оптимальні відстані.

Принципи озеленення вулиць для захисту пішоходів від надмірної інсоляції, а також сонцезахисту приміщень у будівлях пов'язані насамперед з орієнтацією вулиць за сторонами світу. Різними вони будуть за широтою і меридіальною орієнтаціями. Орієнтація відібраних вулиць здебільшого з Пн. Сх. на Пд. Зх., тобто вона близька до діагонального розташування. Широтну орієнтацію зі сходу на захід мають вул. В. Великого та Наукова, а меридіальну - вул. Кульпарківська та Тролейбусна (див. табл. 1). Здебільшого умови притінення на відібраних вулицях близькі до оптимальних, при цьому в старому районі завдяки як високим ширококронним насадженням, так і тіні від щільної забудови, а на молодших вулицях - через вдале проектування зелені.

Найпроблемнішими є окремі ділянки вулиць меридіального і діагонального спрямування, оскільки саме тут надходить більше сонячної енергії, особливо в полуденні години. За таких умов найбільшого ефекту могли б дати насадження ряду дерев по обидва боки тротуару, причому дерева між тротуаром і будівлею повинні бути високими. Тому непарна сторона вул. Кульпарківської на окремих ділянках має поганий захист тротуарів у літню пору за наявних резервних площ для додаткових насаджень.

Поганий сонцезахист і на вул. кн. Ольги: хоча іiї peконструкція відбувалась досить давно (близько 30 років тому), але парну сторону тільки недавно почали озеленювати. На значній частині вулиці насаджень немає, а новостворені мають досить хаотичний характер і за асортиментом, і за ритмом.

Водночас шумозахисні та звукоізолюючі можливості придорожніх насаджень на цій території зовсім не продумані як за конструкцією, так і за ажурністю крони. Відсутність кущових видів, особливо у вигляді жи- воплотів, значно погіршує сануючу функціональність зелених смуг.

Загалом, особливості озеленення досліджуваних вулиць можна узагальнити такими висновками:

- вуличні насадження сформовані 3 досить одноманітного асортименту видів;

- у насадженнях переважають традиційні прийоми озеленення без урахування сучасних підходів і можливостей;

- не завжди витримані існуючі норми проектування та будівництва вуличних зелених насаджень;

- часто порушується видовий ритм рослин у випадку заміни втрачених особин;

- недостатня кількість та планувальна структура насаджень за меридіального і діагонального спрямування вулиць.

Розроблення концепції озеленення на період перспективної забудови і робіт щодо реконструкції наявних насаджень, правильний добір асортименту та його розміщення 3 урахуванням містобудівельних норм дасть змогу надати вулицям сучасних привабливих форм, а мешканцям - комфорту і чистоти середовища.

\section{Перелік використаних джерел}

Balakin, V. V. (2015). Printcypi formirovaniia obektov landshaftnosredozashchitnogo ozeleneniia na gorodskikh dorogakh i ulitcakh. [Principles of arrangement of planted shelterbelts in urban streets and roads]. Vestnik Volgogradskogo Gosudarstvennogo Arhitekturno-Stroitelnogo Universiteta. Seriya: Stroitelstvo $i$ Arhitektura, 40(59), 58-72. [In Russian].

Borowski, J., \& Latocha, P. (2006). Dobór drzew i krzewów do warunków przyulicznych Warszawy i miast centralnej Polski. [Trees and shrubs suitable for street conditions in Warsaw and other cities in central Poland]. Rocznik dendrologiczny, 54, 83-93.

Instrukcija (2001). Instrukcija $\mathrm{z}$ tehnichnoi inventaryzacii zelenyh nasadzhen $\mathrm{u}$ mistah ta selyshhah miskogo typu Ukrainy (nakaz Derzhkomitetu budivnyctva, arhitektury ta zhytlovoi polityky N 226 vid 24.12.2001 p. Retrieved from: http://zakon4.rada.gov.ua/laws/show/z0182-02.

Koeser, A., Hauer, R., Norris, K., \& Krouse, R. (2013). Factors influencing long-term street tree survival in Milwaukee, WI, USA. Urban Forestry \& Urban Greening, 12(4), 562-568. https://doi.org/10.1016/j.ufug.2013.05.006 
Kravchuk, V. A., \& Ryzhikov, V. A. (2011). Struktura, sostojanie i ustojchivost drevesnih nasazhdenij v posadkah vdol ulic i dorog v gorodah Belorussii. Prirodopolzovanie, 20, 81-89. [In Russian].

Kurnycka, M. P. (2001). Osoblyvosti zhyttjedijalnosti derevnyh porid $\mathrm{v}$ urbogennyh umovah velykyh mist (na prykladi m. Lvova). Abstract of Doctoral Dissertation for Agricultural Sciences (06.03.01 - Forest Crops and Phytomelioration). Lviv. 19 p. [In Ukrainian].

Litvinenko, S. G, Vikluyk, M. I, \& Blyakharska, L. O. (2017). Pidsumky inventaryzacii zelenyh nasazdzhen mista Chernivci. [The Results of Inventory of Green Plantations in Chernivtsy City]. Scientific Bulletin of UNFU, 27(1), 48-53. https://doi.org/10.15421/40270110.

McPherson, E. G., van Doorn, N., \& de Goede, J. (2016). Structure, function and value of street trees in California, USA. Urban Forestry \& Urban Greening, 17(1), 104-115. https://doi.org/10.1016/j.ufug.2016.03.013

Melnyk, T. I., \& Melnyk, A. V. (2013). Vydovyj sklad i kilkisna uchast derevnyh porid u vulychnyh nasadzhennjah mista Sumy. Naukovyj visnyk Naciona'nogo universystetu bioresursiv $i$ pryrodokorystuvannja Ukrainy. Serija: Lisivnyctvo i dekoratyvne sadivnyctvo, 187(3), 49-54. [In Ukrainian].

Pihalo, O. V. (2014). Osoblyvosti zrostannja vulychnyh nasadzhen v urbogennyh umovah m. Kyjeva. Naukovyj visnyk Nacionalnogo universystetu bioresursiv i pryrodokorystuvannja Ukrainy. Serija: Lisivnyctvo $i$ dekoratyvne sadivnyctvo, 198(1), 180-185. [In Ukrainian]. Retrieved from:

http://nbuv.gov.ua/UJRN/nvnau lis_2014_198(1) 30
Seamans, G. S. (2013). Mainstreaming the environmental benefits of street trees. Urban Forestry \& Urban Greening, 12(1), 2-11. https://doi.org/10.1016/j.ufug.2012.08.004

Suslova, Ye. P. (2017). Riznomanittja ta vikova struktura derevnyh roslyn u vulychnyh nasadzhennjah mista Pokrovsk. [Variety and Age Structure of Woody Plants in the Street Plantations of the City of Pokrovsk]. Scientific Bulletin of UNFU, 27(4), 83-86. https://doi.org/10.15421/40270418. [In Ukrainian].

Szafranko, E. (2012). Wpływ zieleni przyulicznej na kształtowanie krajobrazu miejskiego. Analiza kryteriów doboru roślin. [Influence of green areas beside the streets on the urban landscape. Analysis of plant selection criteria]. Czasopismo Techniczne. Architektura, 6A(19), 179-188

Vailshery, L. S., Jaganmohan, M., \& Nagendra, H. (2013). Effect of street trees on microclimate and air pollution in a tropical city. Urban Forestry \& Urban Greening, 12(3), 408-415. https://doi.org/10.1016/j.ufug.2013.03.002

Atkina, L. I., \& Vishniakova, S. V. (2015). Osobennosti ozeleneniia ulitc s maloetazhnoi zastroikoi g. Nizhniaia Salda Sverdlovski oblasti. [Features of green streets with low-rise buildings Nizhny Salda, Sverdlovsk region]. Lesa Rossii i khoziaistvo v nikh, 4(55), 71-77. [In Russian].

Hanaba, D. V. (2016). Vydove riznomanittja ta fitosanitarnyj stan derevnyh nasadzhen centralnoi chastyny masta Hmelnyckogo. Visnyk nacionalnogo universytetu vodnogo gospodarstva $i$ pryrodokorystuvannja, 2(74), 47-55. [In Ukrainian].

М. П. Курныцька

Наииональный лесотехнический университет Украины, г. Львов, Украина

\title{
АРХИТЕКТУРНО-ПЛАНИРОВОЧНЫЕ ОСОБЕННОСТИ ФОРМИРОВАНИЯ УЛИЧНЫХ НАСАЖДЕНИЙ ГОРОДА ЛЬВОВА
}

\begin{abstract}
Проанализированы принципы, приемы и планировочные особенности озеленения вдоль главных улиц Франковского района г. Львова. Осуществлен обзор современных исследований в области уличного озеленения. Приведена техническая характеристика десяти улиц города по их параметрам, планировочной структуре и ориентации по сторонам света. Изучен породный состав рядовых посадок, который в целом насчитывает 20 видов деревьев. Проанализированы их размещение, условия роста, количественные и качественные показатели озеленения исследованных объектов. Обнаружено присутствие в данном районе всех типичных приемов уличного озеленения. Чаще всего встречаются посадки одного ряда деревьев между проезжей частью и тротуаром или только полосы газона. Значительное преобладание деревьев в лунках обнаружено в условиях плотной застройки района. Установлена зависимость уровня озеленения избранных улиц от характера и времени застройки: в старой части длина участков дороги с зелеными насаждениями колеблется в пределах 46,1-60,6 \%, в то время как новые микрорайоны с магистральными дорогами хорошо озеленены почти по всей длине. Изложены нарушения по размерам посадочных площадей, а также расположение насаждений вдоль улиц. Приведена оценка функциональной способности придорожных зеленых полос. Зафиксированы проблемы при проектировании новых посадок. Сделано обобщение основных недостатков озеленения вдоль отобранных для исследования улиц.
\end{abstract}

Ключевые слова: улицы; рядовые посадки; озеленение; принципы проектирования.

M. P. Kurnytska

Ukrainian National Forestry University, Lviv, Ukraine

\section{SOME ARCHITECTURAL AND PLANNING FEATURES OF STREET LANDSCAPING OF THE CITY OF LVIV}

The work is devoted to the analysis of methods and principles of street landscaping, its planning and compositional features. The city of Lviv is chosen as an example. The objects under research were 10 streets of one of the city's districts, characterized by heavy, often multi-row traffic. The planning features of the streets themselves are analyzed by their length (from 1300 to $3800 \mathrm{~m}$ ) and width (from 6 to $30 \mathrm{~m}$ ). There are separate strips of $6 \mathrm{~m}$ width on two streets. The orientation of the selected streets is mostly from northeast to southwest, that is, close to the diagonal arrangement, but there are both latitudinal and meridian orientations. Tilia platyphyllos Scop., Aesculus hippocastanum L., Acer platanoides L. and Fraxinus excelsior L. (42.0\%; 29.2 \%, $11.5 \%$; $5.5 \%$ correspondingly) are found most frequently. The average age of the examined trees is about 40 years, although there are plantations between the ages of 10-15 and 80-100 years. In this city district all the most typical methods of street landscaping are observed. Most often there are trees planted in one row between the travel section (or carriageway) and the sidewalk or only the strips of lawn. In areas of old buildings trees are growing usually in hollows. There is a direct correlation between the level of street landscaping and the time of their establishment. On the streets with dense buildings length of plant areas are rather small and amount to $46.1-60.6 \%$ respectively. At the same time, new districts with trunk roads are well landscaped on both sides of the street. More than $90 \%$ of the total length of the streets is landscaped. There are 2 rows of trees on both sides, as well as house greening on the considerable length of the road, the width of which is somewhere $60 \mathrm{~m}$. The house greening is observed most often on the old streets. Significant violations of existing norms of designing and construction of street plantations have been detected, namely they are as follows: unacceptably small sizes of hollows prevail on the given objects $(1.0 \times 1.5 \mathrm{~m})$; often inappropriate width of green wayside strips $(1.0$ $1.5 \mathrm{~m})$; close placement of tree trunks to the edge of the carriageway and to the walls of the buildings; in case of lost plants they are substituted by plants of inappropriate kind. Consequently, the sanitary-hygienic properties of street plantations are analyzed. The instructions to increase their functionality are proposed.

Keywords: streets; linear plantations; greening; planning features. 